Article

\title{
Effect of Mechanical and Herbicide Treatments on Weed Densities and Biomass in Two Potato Cultivars
}

\author{
Piotr Barbaś ${ }^{1}$, Barbara Sawicka ${ }^{2, * D}$, Barbara Krochmal Marczak ${ }^{3} \mathbb{D}$ and Piotr Pszczółkowski ${ }^{4}$ (D) \\ 1 Department Agronomy of Potato, Plant Breeding and Acclimatization Institute-National Research Institute, \\ Branch in Jadwisin, Szaniawskiego 15, Str., 05-140 Serock, Poland; p.barbas@ihar.edu.pl \\ 2 Department of Plant Production Technology and Commodities Science, University of Life Sciences in Lublin, \\ Akademicka 15, Str., 20-950 Lublin, Poland \\ 3 Department of Plant Production and Food Safety, Carpathian State University in Krosno, \\ Dmochowskiego 22 Str., 38-400 Krosno, Poland; barbara.marczak@kpu.krosno.pl \\ 4 Experimental Station for Cultivar Assessment of Central Crop Research Centre, Uhnin, \\ 21-211 Dębowa Kłoda, Poland; p.pszczolkowski.inspektor@coboru.gov.pl \\ * Correspondence: barbara.sawicka@up.lublin.pl; Tel.: +48-814-456-787
}

Received: 15 August 2020; Accepted: 30 September 2020; Published: 3 October 2020

check for updates

\begin{abstract}
The effect of potato cultivar and mechanical or herbicide treatments on weed densities and biomass was determined in a research study on a field, conducted from 2007 to 2009 at the Institute of Plant Breeding and Acclimatization. Included in the study were two cultivars and different weed control treatments, including a mechanical method and metribuzin combined with various herbicides and application timings. Chemical methods of controlling weeds were more effective than mechanical methods to reduce weed densities and biomass. The combination of metribuzin with rimsulfuron $+\mathrm{SN}$ oil, applied before potato emergence (PRE), was more effective than the other metribuzin combinations. The weed infestation of potato cv. "Irga" was greater than that of cultivar "Fianna" due to differences in the type of growth.
\end{abstract}

Keywords: potato; cultivars; biodiversity of weeds; mechanical method; chemical method; monocotyledonous weeds; dicotyledonous weeds

\section{Introduction}

Weeds compete with crops for water, light, and nutrients. Due to the long period from planting to covering inter-rows, potatoes are not as competitive as some other crops. In addition, weeds can reduce air circulation in the potato crop and contribute to favorable conditions for potato infection by pathogens. Effective weed control can eliminate the competitive effects of weeds and should be based on detailed knowledge, including factors impacting performance [1-4]. For example, the same herbicide may have varying efficacy depending on the environmental conditions at and after the application time. Other factors include absorption, translocation, and degradation in the plant [5-7]. Selection of herbicides, herbicide combinations, rates, and application timings should be suited to the degree of weed infestation, the optimal date for using agrochemicals, and the combination of herbicides required to eliminate a wide spectrum of weeds [3-8]. Earlier, Pawlonka [8] used metribuzin preand postemergence on potato plants, combined with mechanical treatments, in order to minimize the adverse effect of monoculture on potato yields. However, no publications by other authors concerning the use of metribuzin in mixtures with other herbicides were found. Hence, research was undertaken on the use of metribuzin in combination with other active substances of herbicides, with a different spectrum of action to eliminate both dicotyledonous and monocotyledonous weeds.

The main aim of the research is to develop innovative, effective methods of weed control under the conditions of weed threat, which will provide a larger spectrum of chemical agent action and result in 
weed control efficiency, costs, rate reductions, and impact on the environment. Hence, the intention of the work is use metribuzin (pre- and post-emergence) and the chosen herbicide mixtures (metribuzin + rimsulfuron + ethoxylated isodecyl alcohol; metribuzin + fluazifop-P-butyl; metribuzin + sulfosulfuron $+\mathrm{SN}$ oil) for the control of weeds in the cultivation of two potato cultivars, which will provide a wider spectrum of action of the active substance compared to the mechanical method of combating weeds. This will result in better weed control, a reduction in the dose of herbicides, a reduction in their negative impact on the environment, and a reduction in costs. The selection of these herbicides results from their availability, spectrum of action, and their prices, which is important for farmers, who will make the most economical decision. This research can add value to existing methods. A comparison of chemical weed control methods with mechanical methods that are rarely used today would make it possible to move away from such mechanical methods.

The paper verifies the alternative hypothesis that the use of herbicides and their mixtures, namely, (a) metribuzin-PRE; (b) metribuzin + rimsulfuron + ethoxylated isodecyl alcohol—PRE; (c) metribuzin-POST; (d) metribuzin + rimsulfuron + isodecyl alcohol ethoxylate-PRE; (e) metribuzin + fluazifop-P butyl-POST; (f) metribuzin + sulfosulfuron + SN oil-POST-emergence in potato cultivation will

(a) provide a broader spectrum of action of herbicide chemistry and greater weed control than no weed control and mechanical weed control;

(b) reduce environmental pollution and ensure better effectiveness of chemical treatments, due to the use of lower doses of herbicides, against the null hypothesis that there are no differences between the variants with herbicides and their mixtures and the variant without weed protection and the variant with mechanical weed infestation control in potatoes.

\section{Material and Methods}

Field trials were carried out for three years, from 2007 to 2009, at the Institute of Plant Breeding and Acclimatization-National Research Institute in Jadwisin $\left(52^{\circ} 29^{\prime} \mathrm{N}, 21^{\circ} 03^{\prime} \mathrm{E}\right)$. The soil each year was a sandy loam [9]. The experimental design was randomized sub-blocks in a dependent, split-plot system, with three replications. Two factors were examined in the experiment: the first-order factor was potato cultivars ("Irga", an edible, medium-early, stem-type cultivar, and "Fianna", a medium-late, edible, leaf-like cultivar). The second-order factors were weed control methods, including extensive mechanical treatments (every 2 weeks) from planting until row closure and several metribuzin combinations and application timings. Table 1 shows the combinations, rates, and application timings of herbicide treatments. A nontreated control was included for comparison. Herbicides were applied in $400 \mathrm{dm}^{3} \mathrm{ha}^{-1}$ of water with a backpack sprayer with flat-spray nozzles and a flow rate of $0.35-0.65 \mathrm{dm} \cdot \mathrm{min}^{-1}$ and a pressure of 0.1-0.2 MPa. The plot area for treatments was $31.0 \mathrm{~m}^{2}$, of which $25 \mathrm{~m}^{2}$ was harvested for tuber yields and quality.

\subsection{Agrotechnical Treatments}

The previous crops were winter wheat, and white mustard green manure was plowed the fall before potato planting. The type and timing of tillage for field preparation, fertilizer rates and timing, as well as nutrients provided by the white mustard, are shown in Table 2. After harvesting wheat, nitrogen fertilization was applied in an amount of $50 \mathrm{~kg} \mathrm{~N} \mathrm{ha}^{-1}$, followed by stubble cultivation and the sowing of white mustard in an amount of $20 \mathrm{~kg} \cdot \mathrm{ha}^{-1}$. White mustard, as a green fertilizer for plowing, brings macro- and micronutrients annually in the amount presented in Table 2.

In addition, in autumn each year, preceding planting, mineral phosphorus-potassium fertilization was applied in the amount of $39.3 \mathrm{~kg}$ P.ha ${ }^{-1}$ and $116.2 \mathrm{~kg} \mathrm{~K} \cdot \mathrm{ha}^{-1}$ during prewinter plowing. Nitrogen fertilizers were sown in spring, in the amount of $100 \mathrm{~kg} \mathrm{~N} \mathrm{ha}^{-1}$, mixing them with the soil using a tilling set (cultivator + string roller). The fertilizer doses were determined on the basis of the abundance. Potato tubers were planted by hand in the third decade of April, with a spacing of 
$75 \times 33 \mathrm{~cm}$. The propagating material was in Class C/A. Herbicide spraying was done manually using a backpack sprayer. Nursing treatments were performed in accordance with the requirements of good agricultural practice and the methodological assumptions of the experiment. They consisted of covering ridges and ridging. Herbicides in the following combinations were applied to the freshly formed soil, just before the emergence of the potato (metribuzin $1 \mathrm{~kg} \mathrm{ha}^{-1}$; metribuzin $1 \mathrm{~kg} \mathrm{ha}^{-1}+$ rimsulfuron $40 \mathrm{~g} \mathrm{ha}^{-1}+$ ethoxylated isodecyl alcohol $0.1 \%$ ). After potato emergence, the following preparations were used in reduced doses after prior ridging: metribuzin $0.5 \mathrm{~kg} \mathrm{ha}^{-1}$; metribuzin $0.3 \mathrm{~kg} \mathrm{ha}^{-1}+$ rimsulfuron $30 \mathrm{~g}$ ha + ethoxylated isodecyl alcohol $0.1 \%$; metribuzin $0.3 \mathrm{~kg} \mathrm{ha}^{-1}+$ fluazyfop-P butyl $2 \mathrm{~L} \mathrm{ha}^{-1}$; metribuzin $0.3 \mathrm{~kg} \mathrm{ha}^{-1}+$ sulfosulfuron $26.5 \mathrm{~g} \mathrm{ha}^{-1}+\mathrm{SN}$ oil $1 \mathrm{~L} \mathrm{ha}^{-1}$ (Table 3). In addition, $400 \mathrm{~L} \mathrm{ha}^{-1}$ of water was used for spraying with the herbicides.

Potato protection against diseases and insects (Table 4) was used in accordance with the recommendations of the Institute of Plant Protection, National Research Institute, Poland [11].

Table 1. Characteristics of the herbicides and adjuvants used in the experiment.

\begin{tabular}{|c|c|c|c|c|c|}
\hline Trade Names & Common Names & Formulation & Dosage & $\begin{array}{l}\text { Utility Forms and } \\
\text { Application Date }\end{array}$ & Grace $* * *$ \\
\hline \multicolumn{6}{|c|}{ Herbicides } \\
\hline Apyros 75WG & Sulfosulfuron & $75 \%$ & $26.5 \mathrm{~g} \cdot \mathrm{ha}^{-1}$ & $\begin{array}{l}\text { granules for water } \\
\text { suspension (POST) }\end{array}$ & Not applicable \\
\hline Fusilade Forte 150 EC & Fluazyfop-P butyl & $\begin{array}{l}150 \mathrm{~g} \text { in } 1 \mathrm{~L} \text { of } \\
\text { measure }\end{array}$ & $2 \mathrm{~L} \mathrm{ha}^{-1}$ & $\begin{array}{l}\text { (POST) concentrate for } \\
\text { water suspension }\end{array}$ & Not applicable \\
\hline Sencor $70 \mathrm{WG}$ & Metribuzin & $70 \%$ & $\begin{array}{c}0.5\left(\mathrm{PRE}^{*}\right) \text { or } 0.3 \mathrm{~kg} \mathrm{ha}^{-1} \\
\left(\mathrm{POST}^{* *}\right)\end{array}$ & $\begin{array}{c}\text { granules for water } \\
\text { suspension }\end{array}$ & 42 days \\
\hline Titus 25 WG & Rimsulfuron & $25 \%$ & $40 \mathrm{~g} \mathrm{ha}^{-1}$ & $\begin{array}{l}\text { granules for water } \\
\text { suspension (POST) }\end{array}$ & Not applicable \\
\hline \multicolumn{6}{|c|}{ Adjuvants (boosters) } \\
\hline Atpolan 80 SC & SN oil & $76 \%$ & $1 \mathrm{~L} \mathrm{ha}^{-1}$ & $\begin{array}{l}\text { concentrate for water } \\
\text { suspension (POST) }\end{array}$ & Not applicable \\
\hline Trend 90 EC & $\begin{array}{c}\text { ethoxylated } \\
\text { isodecil alcohol }\end{array}$ & $90 \%$ & $0.1 \%$ & $\begin{array}{l}\text { concentrate for water } \\
\text { suspension (PRE) }\end{array}$ & Not applicable \\
\hline
\end{tabular}

Sources: $[10,11] ;{ }^{*}$ before potato emergence (PRE); ${ }^{* *}$ after emergence (POST); *** the period from the day of the last treatment to the day of harvesting plants intended for consumption 
Table 2. Chemical composition of white mustard as a green fertilizer

\begin{tabular}{|c|c|c|c|c|c|c|c|c|c|c|c|c|c|c|}
\hline Specification & $\begin{array}{c}\mathrm{DM} \\
\left(\mathrm{g} \mathrm{kg}^{-1}\right)\end{array}$ & $\begin{array}{c}\text { Ash } \\
\left(\mathrm{g} \mathrm{kg}^{-1} \text { DM }\right)\end{array}$ & $\begin{array}{c}\text { N Total } \\
\left(\mathrm{g} \mathrm{kg}^{-1} \mathrm{DM}\right) \\
\end{array}$ & $\begin{array}{c}\text { N Miner. } \\
\left(\mathrm{g} \mathrm{kg}^{-1} \mathrm{DM}\right)\end{array}$ & $\begin{array}{c}\mathrm{P} \\
\left(\mathrm{g} \mathrm{kg}^{-1} \mathrm{DM}\right) \\
\end{array}$ & $\begin{array}{c}\mathrm{K} \\
\left(\mathrm{g} \mathrm{kg}^{-1} \mathrm{DM}\right) \\
\end{array}$ & $\begin{array}{c}\mathrm{Mg} \\
\left(\mathrm{g} \mathrm{kg}^{-1} \mathrm{DM}\right) \\
\end{array}$ & $\begin{array}{c}\mathrm{Ca} \\
\left(\mathrm{g} \mathrm{kg}^{-1} \mathrm{DM}\right) \\
\end{array}$ & $\begin{array}{c}\mathrm{Na} \\
\left(\mathrm{g} \mathrm{kg}^{-1} \mathrm{DM}\right) \\
\end{array}$ & $\begin{array}{c}\mathrm{Cu} \\
\left(\mathrm{mg} \mathrm{kg}^{-1} \mathrm{DM}\right)\end{array}$ & $\begin{array}{c}\mathrm{Zn} \\
\left(\mathrm{mg} \mathrm{kg}^{-1} \mathrm{DM}\right)\end{array}$ & $\begin{array}{c}\mathrm{Mn} \\
\left(\mathrm{mg} \mathrm{kg}^{-1} \mathrm{DM}\right)\end{array}$ & $\begin{array}{c}\mathrm{Fe} \\
\left(\mathrm{mg} \mathrm{kg}^{-1} \mathrm{DM}\right)\end{array}$ & $\begin{array}{c}\mathrm{Ni} \\
\left(\mathrm{mg} \mathrm{kg}^{-1} \mathrm{DM}\right) \\
\end{array}$ \\
\hline $\begin{array}{l}\text { White } \\
\text { mustard } \\
\text { biomass }\end{array}$ & 454 & 55.1 & 19.2 & 0.8 & 3.1 & 31.6 & 4.5 & 1.2 & 0.8 & 0.4 & 35.4 & 36.0 & 63.4 & 7.05 \\
\hline
\end{tabular}


Table 3. The agricultural treatments in the experiment in the years 2006-2009.

\begin{tabular}{|c|c|c|}
\hline \multicolumn{3}{|c|}{ Autumn 2006-2008 } \\
\hline \multicolumn{3}{|c|}{$\begin{array}{c}\text { Nitrogen fertilization }\left(50 \mathrm{~kg} \mathrm{ha}^{-1}\right) \text { —ammonium nitrate } \\
\text { Tillage }\end{array}$} \\
\hline \multicolumn{3}{|c|}{$\begin{array}{l}\text { white mustard sowing }\left(20 \mathrm{~kg} \mathrm{ha}^{-1}\right) \\
\text { disking of white mustard }\end{array}$} \\
\hline \multirow{2}{*}{\multicolumn{3}{|c|}{$\begin{array}{l}\text { fertilization with phosphorus ( } 39.3 \mathrm{~kg} \mathrm{P} \mathrm{ha}^{-1} \text { in the form of granulated superphosphate) and potassium }\left(116.2 \mathrm{~kg} \mathrm{~K} \mathrm{ha}^{-1} \text { in the }\right. \\
\text { form of } 60 \% \text { potassium salt) }\end{array}$}} \\
\hline & & \\
\hline Spring 2007 & Spring 2008 & Spring 2009 \\
\hline \multicolumn{3}{|c|}{ Tillage and agricultural treatments } \\
\hline Harrowing & Harrowing & Harrowing \\
\hline fertilization of $N\left(100 \mathrm{~kg} \mathrm{ha}^{-1}\right.$ _salmag $)$ & fertilization of $\mathrm{N}\left(100 \mathrm{~kg} \mathrm{ha}^{-1}\right.$ _salmag $)$ & fertilization of $\mathrm{N}\left(100 \mathrm{~kg} \mathrm{ha}^{-1}\right.$-salmag $)$ \\
\hline Cultivation with an aggregate & Cultivation with an aggregate & Cultivation with an aggregate \\
\hline planting of potato seeds - manually & planting of potato seeds-manually & planting of potato seeds - manually \\
\hline Earthing 2 times; in mechanical & Earthing 2 times; in mechanical & Earthing 2 times; in mechanical \\
\hline treatment, earthing and weeding 3 times & treatment, earthing and weeding 4 times & treatment, earthing and weeding 4 times \\
\hline $\begin{array}{l}\text { Herbicide spraying PRE andPOST with } \\
\text { atomic knapsack sprayerHarvest with }\end{array}$ & $\begin{array}{l}\text { Herbicide spraying PRE and POST with } \\
\text { atomic knapsack sprayer }\end{array}$ & $\begin{array}{l}\text { Herbicide spraying PRE and POST with } \\
\text { atomic knapsack sprayer }\end{array}$ \\
\hline potato elevator digger & Harvest with potato elevator digger & Harvest with potato elevator digger \\
\hline
\end{tabular}

Table 4. Potato protection against diseases and insects.

\begin{tabular}{|c|c|c|c|}
\hline \multirow{2}{*}{ Pesticides } & \multicolumn{3}{|c|}{ Years } \\
\hline & 2007 & 2008 & 2009 \\
\hline Fungicides & $\begin{array}{c}\text { chlorothalonil } \\
\text { propamocarb hydrochloride } \\
\mathrm{SC}-2.5 \mathrm{dm}^{3} \mathrm{ha}^{-1} \\
\text { fluazynam-0.4 } \mathrm{L} \\
\text { ha }^{-1} \text { fenamidon }+ \\
\text { mankozeb-1.25 } \mathrm{kg} \mathrm{ha}^{-1} \\
\text { metalaxyl }-\mathrm{M}+ \\
\text { mancozeb-2.5 } \mathrm{kg} \mathrm{ha}^{-1}\end{array}$ & $\begin{array}{c}\text { metalaxyl - M + mancozeb-2.5 } \mathrm{kg} \mathrm{ha}^{-1} \\
\text { chlorothalonil } \\
\text { (tetrachloroisophthalonitrile) }-2 \mathrm{~L} \mathrm{ha}^{-1} \\
\text { propamocarb hydrochloride, } \\
\text { fenamidone-2 } \mathrm{L} \mathrm{ha}^{-1}\end{array}$ & $\begin{array}{c}\text { metalaxyl }-\mathrm{M}+\text { mancozeb-2.5 } \mathrm{kg} \mathrm{ha}^{-1} \\
\text { mancozeb }+ \\
\text { cymoxanil/2-cyano- } N \text {-[(ethylamino) } \\
\text { carbonyl]-2-(methoxyimino) } \\
\text { acetamide }-2 \mathrm{~kg} \mathrm{ha}^{-1} \\
\text { propamocarb hydrochloride, } \\
\text { fenamidone-2 } 2 \mathrm{~L} \mathrm{ha}^{-1}\end{array}$ \\
\hline Insecticides & $\begin{array}{l}\text { thiamethoxam-0.04 } \mathrm{kg} \mathrm{ha}^{-1} \\
\text { acetamiprid—0.08 } \mathrm{kg} \mathrm{ha}^{-1}\end{array}$ & $\begin{array}{l}\text { thiamethoxam }-0.04 \mathrm{~kg} \mathrm{ha}^{-1} \\
\text { thiacloprid-0.75 } \mathrm{L} \mathrm{ha}^{-1} \\
\text { acetamiprid-0.08 } \mathrm{kg} \mathrm{ha}^{-1}\end{array}$ & $\begin{array}{l}\text { imidacloprid-0.25 } \mathrm{L} \mathrm{ha}^{-1} \\
\text { thiacloprid-0.75 } \mathrm{L} \mathrm{ha}^{-1}\end{array}$ \\
\hline
\end{tabular}

Source: $[10,11]$.

\subsection{Assessment of Weeds}

The assessment of weed infestation was carried out using the quadrat method, quantitatively and qualitatively, on three randomly selected $1-\mathrm{m}^{2}$ areas in each plot, after row closure and just before harvest. Weed species were determined, and before potato harvest, when weed plants entered Stage 97 based on the $\mathrm{BBCH}$ scale (BBCH abbreviation comes from the German Biologische Bundesanstalt, Bundessortenamt und $\mathrm{CHemische}$ Industrie), fresh biomass from three randomly selected $1.0 \mathrm{~m}^{2}$ quadrats per plot $[11,12]$ was collected. After measuring fresh weight, samples were dried, and the dry weight was recorded.

A weed species list was established. The number of weeds present in each $1 \mathrm{~m}^{2}$ quadrat was calculated according to the formula

$$
\mathrm{Nw}=\frac{(\mathrm{N} 1+\mathrm{N} 2+\mathrm{N} 3)}{(\mathrm{Nm} \times \mathrm{Qa})}
$$

where

$\mathrm{Nw}-$ number of weeds of a given species growing on an area of $1 \mathrm{~m}^{2}$,

$\mathrm{N} 1, \mathrm{~N} 2, \mathrm{~N} 3$ - number of plants in the quadrat in subsequent measurements (pcs),

$\mathrm{Nm}$-number of measurements,

Qa-quadrat of area $\left(\mathrm{m}^{2}\right)$ [11]. 
Plants were uprooted from soil, segregated by species, and the fresh weight of each species was determined. The weight of a given species was averaged across the three randomly selected quadrats. After drying, the dry weight of weeds was weighed for each species separately, and the weighing results were recorded in an evaluation card. Weed samples were placed in a ventilated room until a constant mass was obtained [11].

\subsection{Meteorological Conditions}

To characterize thermal and humidity conditions in the years of research, data from the meteorological station located at the Institute of Plant Breeding and Acclimatization, National Research Institute, Jadwisin, were used. The conditions of the growing season in 2007-2009 were characterized by varying air temperatures and rainfall (Figure 1, Table 5).

The 2007 and 2008 growing seasons can be described as relatively dry, while 2009 could be characterized as the year with the most favorable humidity and thermal conditions for potato development. Weather data is included in Table 5.

In 2007, the average temperature of the April-September period was $13.7^{\circ} \mathrm{C}$, and this was lower than the long-term average of this period by $0.6^{\circ} \mathrm{C}$. The sum of precipitation was $165.3 \%$ of the norm. Weather conditions in May and August of 2008 exceeded the multiyear norm, and, in the remaining months, there was a noticeable water shortage. The average air temperature in the April-September period was $14.2{ }^{\circ} \mathrm{C}$, and this was lower than the multiyear average by $0.3{ }^{\circ} \mathrm{C}$. The meteorological conditions of the 2009 growing season were varied, but their common feature was a drought period at the beginning of the potato-growing season (Figure 1, Table 5).

Table 5. Precipitation and the hydrothermal coefficient of Sielianinov during the potato vegetation period in 2007-2009 according to the meteorological station of the Plant Breeding and Acclimatization Institute, National Research Institute, Jadwisin.

\begin{tabular}{|c|c|c|c|c|c|c|c|c|}
\hline \multirow{3}{*}{ Year } & \multirow{3}{*}{ Month } & \multicolumn{4}{|c|}{ The Sum of Precipitation in the Month (mm) } & \multirow{3}{*}{$\begin{array}{c}\% \text { of the Long-Term } \\
\text { Norm } \\
(1971-1995)\end{array}$} & \multirow{3}{*}{$\begin{array}{l}\text { Sielianinov } \\
\text { Hydrothermal } \\
\text { Coefficient }\end{array}$} & \multirow{3}{*}{$\begin{array}{l}\text { Evaluation of } \\
\text { the Month ** }\end{array}$} \\
\hline & & \multicolumn{3}{|c|}{ Decade } & \multirow{2}{*}{ Month } & & & \\
\hline & & 1 & 2 & 3 & & & & \\
\hline \multirow{4}{*}{2007} & May & 11.6 & 28.7 & 38.1 & 78.4 & $75-125$ & 1.93 & Quite humid \\
\hline & June & 30.4 & 13.6 & 65.6 & 109.6 & $75-125$ & 2.32 & Humid \\
\hline & July & 30.1 & 6.4 & 17.6 & 54.1 & $50-74$ & 0.99 & Dry \\
\hline & Total & 170.4 & 118.9 & 146.8 & 436.4 & - & - & - \\
\hline \multirow[b]{4}{*}{2008} & April & 11.4 & 12.9 & 5.0 & 29.3 & $25-49$ & 1.36 & Optimum \\
\hline & May & 36.8 & 12.8 & 13.3 & 62.9 & $50-74$ & 1.64 & Quite humid \\
\hline & June & 0.0 & 21.0 & 22.5 & 43.5 & $25-49$ & 0.84 & Dry \\
\hline & July & 20.2 & 38.2 & 10.4 & 68.8 & $50-74$ & 1.22 & Quite dry \\
\hline \multirow{7}{*}{2009} & April & 0.0 & 0.0 & 0.0 & 0.0 & $<25$ & 0.0 & Extremely dry \\
\hline & May & 8.8 & 13.3 & 58.7 & 80.8 & $75-125$ & 2.12 & Humid \\
\hline & June & 30.2 & 17.5 & 24.7 & 72.4 & $50-74$ & 1.38 & Optimum \\
\hline & July & 36.8 & 20.5 & 28.3 & 85.6 & $75-125$ & 1.28 & Quite dry \\
\hline & August & 12.5 & 48.5 & 22.1 & 83.1 & $75-125$ & 1.54 & Optimum \\
\hline & September & 8.2 & 4.7 & 5.9 & 18.8 & $<25$ & 0.44 & Very dry \\
\hline & Total & 96.5 & 104.5 & 139.7 & 340.7 & - & - & - \\
\hline
\end{tabular}

** Hydrothermal coefficient according to Sielianinov: extremely dry (ed) $\rightarrow \mathrm{k} \leq 0.4$; very dry (vd) $\rightarrow 0.4<\mathrm{k} \leq 0.7$; dry (d) $\rightarrow 0.7<\mathrm{k} \leq 1.0$; quite dry (Qd) $\rightarrow 1.0<\mathrm{k} \leq 1.3$; optimum (o) $\rightarrow 1.3<\mathrm{k} \leq 1.6$; quite humid (pd) $\rightarrow 1.6<\mathrm{k} \leq 2.0$; humid $(\mathrm{w}) \rightarrow 2.0<\mathrm{k} \leq 2.5$; very humid $(\mathrm{vh}) \rightarrow 2.5<\mathrm{k} \leq 3.0$; extremely moist $(\mathrm{em}) \rightarrow \mathrm{k}>3.0$. 


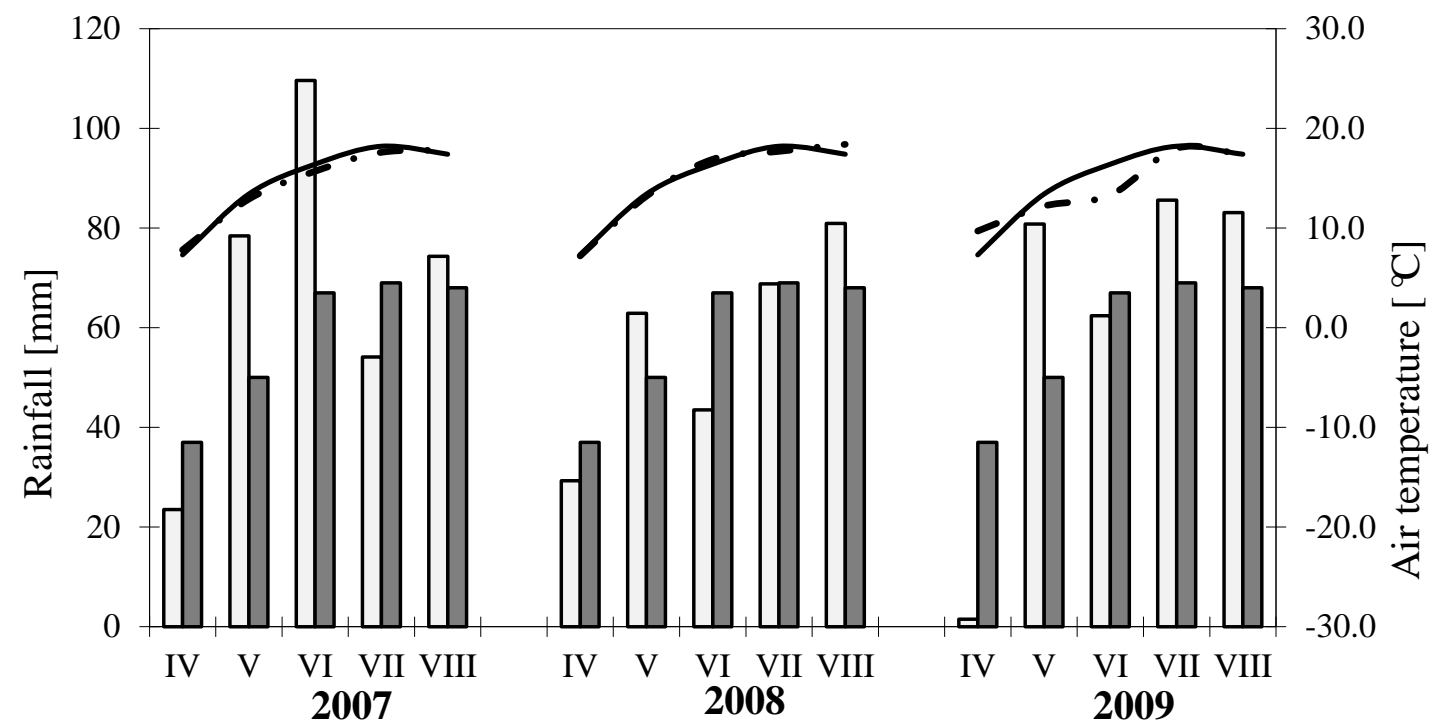

Monthly sum of rainfalls in 2007-2009

- - Mean air temperature in 2007-2009

Monthy sum of rainfalls in 1971-2006

Mean air temperature in 1971-2006

Figure 1. Precipitation and air temperature during the potato-growing season according to the meteorological station of the Institute of Plant Breeding and Seed Production, National Research Institute, Jadwisin (2007-2009), against the background of the long-term average.

\subsection{Statistical Analyses}

SAS v.9.2 software was used for statistical analyses [13]. The factors for the models were (years $\times$ cultivars $\times$ weed control treatment), and variance and multiple Tukey's $t$-tests were determined at significance level $p_{0.05}$. The significance of sources of variation was tested using the Fischer-Snedecor F-test [14].

The averaged data are given: for cultivars-means for treatments, years, and repetitions; in the case of care treatments—averages for cultivars, years, and repetitions; in the case of years-averages for treatments, cultivars, and repetitions.

\section{Results}

\subsection{Soil Conditions}

Information on the value of soils, on which research with potato are presented in Tables 6 and 7.

Table 6. The granulometric composition of the soil (\%).

\begin{tabular}{|c|c|c|c|c|c|}
\hline \multirow{2}{*}{ Years } & \multicolumn{3}{|c|}{$\begin{array}{l}\text { Percentage of Fraction with Diameter } \\
\text { (mm Diameter) }\end{array}$} & \multirow{2}{*}{$\begin{array}{l}\text { Grain Size } \\
\text { Subgroup }\end{array}$} & \multirow{2}{*}{$\begin{array}{l}\text { Soil-Agricultural } \\
\text { Complex }\end{array}$} \\
\hline & $2.0-0.05$ & $0.05-0.002$ & $<0.002$ & & \\
\hline 2007 & 72.0 & 24.0 & 4.0 & Sandy loam & Rye complex \\
\hline 2008 & 71.0 & 26.0 & 3.0 & Sandy loam & Rye complex \\
\hline 2009 & 72.0 & 24.0 & 4.0 & Sandy loam & Rye complex \\
\hline
\end{tabular}

Source: Results were determined at the Chemical and Agricultural Station in Wesoła, near Warsaw. The determinations were made according to the applicable methods and standards $[9,15,16]$. 
Table 7. Physicochemical properties of soil in Jadwisin (2007-2009).

\begin{tabular}{|c|c|c|c|c|c|}
\hline \multirow{2}{*}{ Years } & \multicolumn{3}{|c|}{$\begin{array}{l}\text { Content of Available Forms } \\
\left(\mathrm{mg} \cdot 100 \mathrm{~g}^{-1} \mathrm{DM} \text { of Soil) }\right.\end{array}$} & \multirow{2}{*}{ pH (1M KCl) } & \multirow{2}{*}{$\begin{array}{c}\text { Content of } \\
\text { Organic Substance (\%) }\end{array}$} \\
\hline & $\mathrm{P}_{2} \mathrm{O}_{5}$ & $\mathrm{~K}_{2} \mathrm{O}$ & Mg & & \\
\hline 2007 & 23.9 & 22.2 & 20.0 & 4.7 & 0.73 \\
\hline 2008 & 9.9 & 16.8 & 15.5 & 5.4 & 0.68 \\
\hline 2009 & 3.9 & 7.3 & 6.0 & 5.0 & 0.70 \\
\hline
\end{tabular}

Source: Results were made at the Chemical and Agricultural Station in Wesoła. The determinations were made according to the applicable methods and standards [15-22].

\subsection{Weed Species}

In the plantation, before the row closure of plants, only two species of monocotyledonous weeds (Echinochloa crus-galli-cockspur grass or barnyard grass (ECHCG) and Agropyron repens-quackgrass (AGRRE)) and four species of dicotyledonous weeds (Chenopodium album-common lambsquarters (CHEAL); Convolvulus arvensis—bindweed (CONAR); Erodium cicutarium-redstem filaree (EROCI); Viola arvensis-field violet (VIOAR)) were recorded. Both the cultivars and methods of weed control, as well as meteorological conditions in the years of research, shaped the floristic composition of weeds that were recorded (Table 8). Weed control methods, cultivars, and years of research differentiated the composition and number of weeds found on the potato plantation. The dominant monocotyledonous species was ECHCG, while the main dicotyledonous species was VIOAR. The least ECHCG was recorded on variants with the application of the mixture of herbicides metribuzin + sulfosulfuron + SN oil POST (Variant 8) and preparations metribuzin + rimsulfuron + ethoxylated isodecyl alcohol, used before crop emergence (Variant 4), compared to the control variant and with the mechanical weed control method (Variant 2). AGRRE was dominant in the variant where the metribuzin and metribuzin + rimsulfuron + ethoxylated isodecyl alcohol mixture was used to control weeds, applied PRE. The least dominance of this weed species was recorded after the application of the mixture of metribuzin + fluazyfop-P butyl (variant 7) and metribuzin + sulfosulfuron + SN oil (Variant 8). CHEAL was best destroyed by a mixture of metribuzin + rimsulfuron + ethoxylated isodecyl alcohol preparations, applied before the potato emerges (Variant 4). Field bindweed was best limited by metribuzin applied after crop emergence. EROCI was best removed when metribuzin + rimsulfuron + ethoxylated isodecyl alcohol was applied PRE and with metribuzin applied after potatoes emergence. VIOAR was the least numerous when applying the mixture of metribuzin + sulfosulfuron + SN oil.

Higher weed infestation before row closure was recorded in the medium-early "Irga" cultivar than the medium-late "Fianna", but only in the case of ECHCG. In the case of EROCI, on the other hand, the "Fianna" cultivar was more weeded. Weed infestation with species such as AGRRE, CHEAL, CONAR, and VIOAR did not differentiate the potato cultivars (Table 8).

ECHCG turned out to be the relatively dominant weed species in the years 2007 and 2008; in 2009, the dominating weed was VIOAR, which could possibly be associated with the used forecrop of potato. AGRRE was not present at row closure in the fairly humid conditions of 2008, and CONAR was not present in 2007 and 2008. CHEAL, VIOAR, and CONAR were most frequently recorded in the potato canopy in the quite-dry conditions of 2009. Only the size of EROCI did not significantly depend on growing-season conditions (Table 8).

Species composition of weeds before potato harvest was of little variation. The state and structure of weed infestation in variants with chemical plant protection, compared to mechanical cultivation and the control variant, were similar to the weed infestation determined before shorting the rows. In the species composition of weeds, determined before harvesting, monocotyledons taxa species predominated, with ECHCG dominating (Table 9). 
Table 8. Species composition and the number of monocotyledonous and dicotyledonous weeds before the closure of potato rows, depending on cultivar, weed control method, and year $\left(\mathrm{pcs} \mathrm{m}^{2}\right)$.

\begin{tabular}{|c|c|c|c|c|c|c|c|}
\hline \multirow{2}{*}{\multicolumn{2}{|c|}{ Experiment Factors }} & \multicolumn{6}{|c|}{ Species According WSSA *** } \\
\hline & & ECHCG & AGRRE & CHEAL & CONAR & EROCI & VIOAR \\
\hline \multirow{3}{*}{ Cultivar } & "Irga" & 6.6 & 0.8 & 1.1 & 0.4 & 0.0 & 3.6 \\
\hline & "Fianna" & 5.4 & 0.7 & 1.3 & 0.3 & 0.5 & 3.1 \\
\hline & $\mathrm{LSD}_{p 0.05}$ & 1.0 & ns ** & ns & ns & 0.2 & ns \\
\hline \multirow{9}{*}{$\begin{array}{l}\text { Weed control } \\
\text { methods * }\end{array}$} & 1 & 14.9 & 0.9 & 5.4 & 1.2 & 1.8 & 9.3 \\
\hline & 2 & 6.5 & 0.7 & 2.7 & 0.6 & 0.2 & 5.9 \\
\hline & 3 & 5.3 & 0.7 & 0.2 & 0.3 & 0.1 & 3.8 \\
\hline & 4 & 3.0 & 0.7 & 0.0 & 0.2 & 0.0 & 1.8 \\
\hline & 5 & 5.4 & 1.0 & 0.2 & 0.0 & 0.0 & 1.6 \\
\hline & 6 & 5.6 & 1.1 & 1.0 & 0.1 & 0.1 & 1.8 \\
\hline & 7 & 4.5 & 0.5 & 0.2 & 0.2 & 0.2 & 1.6 \\
\hline & 8 & 3.0 & 0.6 & 0.2 & 0.2 & 0.2 & 0.7 \\
\hline & $\mathrm{LSD}_{p 0.05}$ & 3.3 & ns & 1.5 & 0.8 & 0.8 & 2.7 \\
\hline \multirow{4}{*}{ Years } & 2007 & 5.1 & 1.7 & 0.1 & 0.0 & 0.5 & 1.6 \\
\hline & 2008 & 10.1 & 0.0 & 0.6 & 0.0 & 0.4 & 0.4 \\
\hline & 2009 & 2.8 & 0.5 & 2.9 & 0.9 & 0.0 & 8.0 \\
\hline & $\mathrm{LSD}_{p 0.05}$ & 1.5 & 0.5 & 0.7 & 0.4 & ns & 1.2 \\
\hline \multicolumn{2}{|c|}{ Mean } & 6.0 & 0.7 & 1.2 & 0.3 & 0.3 & 3.3 \\
\hline
\end{tabular}

Source: own research; * (1) Control variant-without chemical protection; (2) extensive mechanical weeding (every 2 weeks) from planting to closure of the rows; (3) metribuzin $1 \mathrm{~kg} \mathrm{ha}^{-1}$-PRE; (4) metribuzin $0.3 \mathrm{~kg} \mathrm{ha}^{-1}+$ rimsulfuron $40 \mathrm{gha}^{-1}+$ ethoxylated isodecyl alcohol $0.1 \%$-PRE; (5) metribuzin $0.5 \mathrm{~kg} \mathrm{ha}^{-1}$-POST; (6) metribuzin 0.3 $\mathrm{kg} \mathrm{ha}^{-1}+$ rimsulfuron $30 \mathrm{~g} \mathrm{ha}^{-1}+$ ethoxylated isodecyl alcohol $0.1 \%$-PRE; (7) metribuzin $0.3 \mathrm{~kg} \mathrm{ha}^{-1}+$ fluazifop-P butyl $2 \mathrm{~L} \mathrm{ha}^{-1}$-POST; (8) metribuzin $0.3 \mathrm{~kg} \mathrm{ha}^{-1}+$ ulfosulfuron $26.5 \mathrm{~g} \mathrm{ha}^{-1}+\mathrm{SN}$ oil $1 \mathrm{~L} \mathrm{ha}^{-1}$-POST; ns ${ }^{* *}$ - not significant at the level $p_{0.05} ;{ }^{* * *}$ AGRRE-Agropyron repens; ECHCG-Echinochloa crus-galli; CHEAL-Chenopodium album; CONAR—Convolvulus arvensis; EROCI—Erodium cicutarium; VIOAR_Viola arvensis [23].

The morphological and physiological features of the studied cultivars differentiated only in the number of ECHCG, VIOAR, and EROCI. The first two were more numerous in the cultivar "Irga" than "Fianna", while, in the last cultivar, it was the opposite. The monocotyledonous weed community was most effectively limited by the following treatments: variant 4 (metribuzin + rimsulfuron + ethoxylated isodecyl alcohol), variant 7 (metribuzin + fluazifop-P butyl), variant 8 (metribuzin + sulfosulfuron + SN oil) (Table 4), limiting their occurrence in comparison with mechanical treatments and the control variant. Dicotyledonous species were eliminated to the greatest extent on Sites 5 (metribuzin) and vriant 8 (metribuzin + sulfosulfuron). Homologous in terms of this feature turned out to be Variant 6 (metribuzin + rimsulfuron + ethoxylated isodecyl alcohol), Variant 7 (metribuzin + fluazifop-P butyl), Variant 5 (Sencor), and Variant 8 (metribuzin + sulfosulfuran $+\mathrm{SN}$ oil), on which these herbicides were used after potato emergence. Potato vegetation conditions also significantly differentiated the number and species composition of weeds. Higher numbers of ECHCG were recorded in 2008, with high rainfall in the period of July-August preceding the potato harvest, while there were high numbers of CHEAL, CONAR, and VIOAR in 2009, as it was quite a dry year (Table 9).

The fresh matter of weeds before harvest was $254.1 \mathrm{~g}$ on average, whereas their average air-dry matter was $102.8 \mathrm{~g} \mathrm{~m}^{-2}$. The weed mass at the end of the growing season was differentiated by cultivars, weed control methods, and years of research (Table 10).

Among the compared cultivars, the medium-early "Irga" was more weeded, the shoots of which dried up earlier and ended the growing season earlier than the medium-late cultivar "Fianna". The best herbicidal effect was achieved using mixtures of the metribuzin + rimsulfuron + ethoxylated isodecyl alcohol (Variant 4) and Sencor + Apyros + Atpolan (Variant 8). Variants 4 and 8 proved to be homologous in terms of this feature. Both fresh and air-dry matter of weeds were the highest in the fairly humid conditions of 2008 and the lowest in 2009, a fairly dry year (Table 10). 
Table 9. Species composition and number of mono- and dicotyledonous weeds before potato harvest, depending on cultivar, weed control method, and year (pcs. $\mathrm{m}^{-2}$ ).

\begin{tabular}{|c|c|c|c|c|c|c|c|c|c|}
\hline \multicolumn{2}{|c|}{ Experiment Factors } & \multirow{2}{*}{$\begin{array}{c}\text { ECHCG } \\
8.3\end{array}$} & \multirow{2}{*}{$\begin{array}{c}\text { AGRRE } \\
1.4\end{array}$} & \multirow{2}{*}{$\begin{array}{c}\text { CAPBP } \\
0.3\end{array}$} & \multirow{2}{*}{$\frac{\text { CHEAL }}{2.4}$} & \multirow{2}{*}{$\frac{\text { CONAR }}{1.6}$} & \multirow{2}{*}{$\frac{\text { EROCI }}{0.0}$} & \multirow{2}{*}{$\frac{\text { SONAR }}{0.04}$} & \multirow{2}{*}{$\begin{array}{c}\text { VIOAR } \\
4.7\end{array}$} \\
\hline & "Irga" & & & & & & & & \\
\hline Cultivars & "Fianna" & 6.4 & 1.5 & 0.0 & 2.0 & 1.2 & 0.5 & 0.01 & 3.4 \\
\hline & $\mathrm{LSD}_{p 0.05}$ & 1.3 & $\mathrm{~ns}^{* *}$ & ns & ns & ns & 0.1 & ns & 1.2 \\
\hline \multirow{9}{*}{$\begin{array}{l}\text { Weed control } \\
\text { methods* }\end{array}$} & 1 & 16.2 & 1.8 & 1.6 & 7.4 & 2.5 & 1.0 & 0.10 & 8.6 \\
\hline & 2 & 8.4 & 2.0 & 0.0 & 4.3 & 1.8 & 0.3 & 0.05 & 6.6 \\
\hline & 3 & 7.6 & 1.3 & 0.0 & 1.5 & 1.8 & 0.2 & 0.00 & 6.5 \\
\hline & 4 & 4.8 & 1.7 & 0.0 & 0.6 & 1.0 & 0.0 & 0.00 & 2.8 \\
\hline & 5 & 6.0 & 2.1 & 0.0 & 0.7 & 1.0 & 0.0 & 0.00 & 1.5 \\
\hline & 6 & 6.7 & 1.2 & 0.0 & 1.1 & 1.0 & 0.2 & 0.00 & 2.8 \\
\hline & 7 & 5.7 & 0.8 & 0.0 & 1.3 & 1.3 & 0.3 & 0.00 & 2.2 \\
\hline & 8 & 3.2 & 1.0 & 0.0 & 0.7 & 0.8 & 0.0 & 0.00 & 1.4 \\
\hline & $\mathrm{LSD}_{p 0.05}$ & 4.0 & ns & $\mathrm{ns}$ & 1.8 & $\mathrm{~ns}$ & 0.6 & ns & 4.2 \\
\hline \multirow{4}{*}{ Years } & 2007 & 4.3 & 3.5 & 0.0 & 0.8 & 0.6 & 0.4 & 0.00 & 0.6 \\
\hline & 2008 & 12.4 & 0.1 & 0.0 & 1.6 & 0.5 & 0.4 & 0.00 & 0.5 \\
\hline & 2009 & 5.4 & 0.8 & 0.6 & 4.2 & 3.2 & 0.0 & 0.08 & 11.0 \\
\hline & $\mathrm{LSD}_{p 0.05}$ & 1.8 & 0.8 & ns & 0.8 & 0.9 & Ns & ns & 1.9 \\
\hline \multicolumn{2}{|c|}{ Mean } & 7.3 & 1.4 & 0.2 & 2.2 & 1.4 & 0.2 & 0.02 & 4.0 \\
\hline
\end{tabular}

Table 10. Fresh and air-dry matter of weeds and their number before potato harvest, depending on cultivar, weed control method, and year.

\begin{tabular}{|c|c|c|c|c|c|}
\hline \multirow{2}{*}{\multicolumn{2}{|c|}{ Experiment Factors }} & \multicolumn{2}{|c|}{ Weed Matter $\left(\mathrm{g} \cdot \mathrm{m}^{-2}\right)$} & \multicolumn{2}{|c|}{ The Number of Weeds (pcs m²) } \\
\hline & 015 & Fresh Matter & Air-Dry Matter & Monocotyledonous & Dicotyledonous \\
\hline \multirow{3}{*}{ Cultivars } & "Irga" & 286.7 & 116.9 & 9.7 & 9.0 \\
\hline & "Fianna" & 221.5 & 88.7 & 7.9 & 7.1 \\
\hline & $\mathrm{LSD}_{p 0.05}$ & 38.6 & 16.1 & ns ** & 1.6 \\
\hline \multirow{9}{*}{$\begin{array}{l}\text { Weed control } \\
\text { methods }\end{array}$} & 1 & 576.9 & 236.7 & 18.0 & 21.2 \\
\hline & 2 & 321.1 & 142.7 & 10.4 & 13.0 \\
\hline & 3 & 231.7 & 76.7 & 8.9 & 10.0 \\
\hline & 4 & 111.4 & 55.8 & 6.5 & 4.4 \\
\hline & 5 & 260.6 & 90.1 & 8.1 & 3.2 \\
\hline & 6 & 227.5 & 94.5 & 7.9 & 5.1 \\
\hline & 7 & 142.5 & 63.1 & 6.5 & 5.1 \\
\hline & 8 & 141.1 & 62.9 & 4.2 & 2.9 \\
\hline & $\mathrm{LSD}_{p 0.05}$ & 120.6 & 50.4 & 4.3 & 4.9 \\
\hline \multirow{4}{*}{ Years } & 2007 & 276.7 & 114.0 & 7.8 & 2.4 \\
\hline & 2008 & 295.3 & 132.2 & 12.5 & 3.0 \\
\hline & 2009 & 190.3 & 62.2 & 6.2 & 19.0 \\
\hline & $\mathrm{LSD}_{p 0.05}$ & 56.7 & 23.7 & 2.0 & 2.3 \\
\hline \multicolumn{2}{|c|}{ Mean } & 254,1 & 102.8 & 8.8 & 8.1 \\
\hline
\end{tabular}

Source: own research; ${ }^{*}$ explanations as in Table $7 ;{ }^{* *}$ not significant at the level $p_{0.05}$.

In the case of the fresh mass of weeds assessed before the rows were closed, a significant interaction of cultivars $\times$ years was found. The medium-early cultivar "Irga" showed a significantly higher weed weight than the medium-late cultivar "Fianna", but only in 2009, which were characterized by lower humidity in May-June than in 2007. Before the harvest, however, both cultivars showed a similar response to the conditions in the years of research (Table 11). 
Table 11. Fresh matter of weeds depending on the cultivar and year (average for weed control methods).

\begin{tabular}{cccc}
\hline \multirow{2}{*}{ Cultivars } & \multicolumn{3}{c}{ Years } \\
\cline { 2 - 4 } & $\mathbf{2 0 0 7}$ & $\mathbf{2 0 0 8}$ & $\mathbf{2 0 0 9}$ \\
\hline & \multicolumn{2}{c}{ Before row closing } \\
\hline “Irga" & 283.1 & 310.8 & 265.0 \\
“Fianna" & 270.2 & 279.7 & 114.3 \\
\hline LSD $_{p 0.05}$ & \multicolumn{3}{c}{36.6} \\
\hline & Before tuber harvest \\
\hline "Irga" & 125.4 & 142.1 & 83.2 \\
\hline "Fianna" & 102.7 & 122.3 \\
\hline LSD $_{p 0.05}$ & & 15.3 & 41.0 \\
\hline
\end{tabular}

In the experiment, the number of monocotyledonous weeds before the potato harvest was $8.8 \mathrm{pcs} \cdot \mathrm{m}^{-2}$; for dicotyledonous weeds, it was $8.1 \mathrm{pcs} \cdot \mathrm{m}^{-2}$. The reduction in the number of monocotyledonous and dicotyledonous weeds was higher in the case of mechanical and chemical care using various herbicides than in mechanical weed control alone. The lowest number of these species, for both classes, was recorded after using the mixture of herbicides Sencor + Apyros + Atpolan (Variant 8) to regulate weed infestation. In the case of the number of monocotyledonous weeds, Variants 4, 7, and 6, and, in the case of dicotyledonous weeds, the combinations of 4, 5, 6, and 7 proved to be homologous in terms of this characteristic. The highest number of monocotyledonous and dicotyledonous weeds was recorded in 2008 and 2009, respectively, while the smallest number was in 2009 and 2007, respectively, as a result of the weather conditions prevailing during the potato growing season (Table 9). In 2009, the cultivar "Irga", with a stem habit, reacted with more weed infestation than the leaf cultivar "Fianna", both before closing the inter-rows and before harvesting the tubers (Table 12).

Table 12. The number weeds per $1 \mathrm{~m}^{2}$, depending on the cultivar and year (average for weed control methods).

\begin{tabular}{cccc}
\hline \multirow{2}{*}{ Cultivars } & \multicolumn{3}{c}{ Years } \\
\cline { 2 - 4 } & $\mathbf{2 0 0 7}$ & $\mathbf{2 0 0 8}$ & $\mathbf{2 0 0 9}$ \\
\hline & \multicolumn{2}{c}{ Before row closing } \\
\hline “Irga" & 8.7 & 11.9 & 17.0 \\
“Fianna" & 9.6 & 11.7 & 13.2 \\
\hline LSD $_{p 0.05}$ & \multicolumn{2}{c}{3.5} \\
\hline "Irga" & Before tuber harvest \\
\hline "Fianna" & 10.7 & 15.2 & 31.0 \\
\hline LSD $_{p 0.05}$ & 10.4 & 15.7 & 19.7 \\
\hline
\end{tabular}

\section{Discussion}

The size of potato yields is largely determined by weeds, and the number, size of the air-dried matter of weeds, and their species composition play a significant role [23-28]. The lowest number of weeds in the tests, regardless of the date of weed infestation measurement timing, was recorded after using the mixture of metribuzin + sulfosulfuran $+\mathrm{SN}$ oil, and the highest number of weeds found in the tests was after the application of metribuzin before the emergence of the crop. Mechanical weed control reduced the number of weeds by twice as much as the control variant. These results were confirmed in the studies of Ciesielska and Wysmułek [29]. In their opinion, metribuzin, regardless of 
the date of use, is characterized by a wide spectrum of weed control, while the addition of rimsulfuron and the ethoxylated isodecyl alcohol adjuvant caused the majority of weeds present in the potato crop to be destroyed by $87-100 \%$. Nowak et al. [30] and Ilić et al. [31] confirmed the improvement of herbicide effectiveness due to the addition of adjuvants to the working liquid. These are chemical substances of organic or inorganic origin, which directly or indirectly affect the herbicidal activity of the herbicide's active substance or change the usable properties of the formulation and application liquid [31-33]. In addition, adjuvants prevent the crystallization of the utilized liquid on the surface of plants and delay its drying, causing an increase in the adhesion and solubility of the herbicide and better hydration of the leaf epidermis [24,31,34-39].

The effect of herbicides is largely dependent on the thermal conditions during the application of the herbicide and a few days after the procedure. This was also confirmed by other authors $[3,40,41]$. According to Gugała et al. [40], a higher temperature promotes increased herbicide adsorption and translocation. Air humidity is also positively correlated with herbicide effects. In conditions of higher humidity, herbicide uptake increases because the used liquid evaporates more slowly from the leaf surface, and, as a consequence, there is a greater amount of agent that can penetrate plant tissues [1,42]. In addition, in conditions of high humidity, the movement of the herbicide in the plant from its penetration to the site of action is much faster than in the case of low humidity [43-46]. However, as suggested by Lavlesh et al. [5], with excessive humidity, there may be a danger of greater herbicide leaching, faster root uptake, and, therefore, increased plant toxicity. Toxicity and degradation rate of biocides, according to Awasthi et al. [45] and Jezierska and Frac [47], depend primarily on their dose and the structure of the active substance that is the basic plant protection product, which can also be a cause of the inhibition and growth of microorganisms.

With Zarzecka et al. [48], the smallest number of weeds were observed on variants sprayed with metribuzin, while the number was significantly higher after using flurochloridon and purely mechanical treatments. Additionally, Tomczak et al. [49] demonstrated the high effectiveness of metribuzin and mixtures of prosulfocarb and metribuzin in weed control in potato cultivation. Pszczółkowski and Sawicka [50] obtained the best results of eliminating monocotyledonous weeds after applying linuron, and they limited dicotyledonous weeds after using a mixture of linuron + clomazone. In the study of Wichrowska [51], the most effective chemical in controlling weeds was linuron, reducing the population size by $80.3 \%$, especially of dicotyledonous weeds. The least effective in weed control was promethrin used before potato plant emergence.

ECHCG and AGRRE were the most abundant among the monocotyledonous weed species, while CHEAL was the most abundant of the dicotyledonous species. Similar results were also obtained by Gugała et al. [40] and Baranowska et al. [52]. During the vegetation period, these authors showed the dominance of taxa of the following weed species: AGRRE-19.8\%, ECHCG-13.2\%, VIOAR-12.1\%, and CHEAL-11.2\%. A similar tendency also appeared before potato tuber harvesting. AGRRE was the most frequently encountered weed (25.9\%), followed by ECHCG (14.7\%) and CHEAL (20.3\%).

Cultivars were another factor that differentiated potato weed infestation. The difference in weed infestation observed between the two examined potato cultivars may be determined by such features as volume of foliage, plant growth rate, morphological and anatomical type, and resistance to abiotic stress. The highest fresh and dry mass of weeds was found in the medium-early cultivar, with a stalk habit, as well as a shorter vegetation period. A medium-late cultivar turned out to be significantly less weedy, with a leaf habit. These results show that potato cultivars with a strong, erect shoot growth habit (shorter stems, more branching, and a denser and taller canopy in the early stages of plant vegetation) may be less susceptible to weed interference than cultivars with lofty plant habit. Similar observations were made by Zarzecka et al. [50] and Baranowska et al. [52]. The optimal time for weed management and the formation of the physiological age of tubers have not been thoroughly investigated and probably vary by cultivar. These dependencies should be established in future research.

The varied response of the studied cultivars to the meteorological conditions of the growing season, in the case of both the number and fresh mass of weeds, could be explained by a different plant habit, 
as well as by the length of the vegetation period. The medium-early "Irga" cultivar is characterized by a stem habit that is more favorable to weed infestation, while the middle-late "Fianna" leaf type cultivar shaded the soil more and thus prevented strong weed infestation. Other authors shared similar observations $[48-50,53]$. In the Polish register of cultivars, and, currently, in the EU register, there is a very large assortment of potato cultivars with different physiological and morphological types and different production possibilities. Therefore, it is necessary to determine not only the potential of the potato cultivars and lines currently grown in Poland but also to test them with biotic and abiotic stresses, including the response to herbicides.

Weed management in the conditions of the changing climate in recent years requires the integration of methods and strategies and a change in the way they are perceived. Weeds in potato crops must be combated in a comprehensive, targeted, and proactive manner. Understanding the interactions between weed control methods and the weed spectrum, as well as managing the crop system to prevent and discourage weeds and keep the level of weed seed in the soil low, is essential for effective weed management in all crop systems [50,53]. Good agricultural and tillage practices, including well-planned crop rotation, planting of cover crops, as well as good sanitary practices [10], optimal row spacing, and early planting dates are important aspects of weed management not only in organic systems but also in other cultivation systems $[54,55]$. Timely mechanical weed control, before the rows of potato plants close, can eliminate many early weed species. In this regard, the selection of appropriate potato cultivars that have a fast initial growth rate and create a leaf canopy capable of controlling weeds can help to reduce weed infestation and, thereby, increase yield. For this purpose, further research, with the participation of potato breeders, is needed on new creations of cultivars that will allow the reduction of primary weed infestation in potato cultivation.

Thanks to the conducted research, for the first time, a broader spectrum of chemical activity of the active substance metribuzin was obtained, with better weed control than mechanical treatments alone. The use of lower doses of metribuzin will contribute to reducing the pollution of the natural environment. Moreover, it was proven that the deciduous cultivar "Fianna" contributed to less weed infestation of potato stalks by creating a larger canopy of leaves than the stalk cultivar "Irga".

\section{Conclusions}

The fresh and air-dry matter of weeds were most limited by the combination of the mixture of metribuzin + rimsulfuron and ethoxylated isodecyl alcohol adjuvant used before potato emergence (PRE). The best effect of reducing the number of monocotyledonous and dicotyledonous weeds was obtained in the potato field with the following preparations: metribuzin + sulfosulfuron $+\mathrm{SN}$ oil applied POST emergence of the potato plants.

The best way to reduce the number of monocotyledonous weeds in the crop of tested cultivars was to use a mixture of herbicides and an adjuvant (metribuzin + sulfosulfuron + SN oil).

The combination of metribuzin + sulfosulfuron + SN oil eliminated CONAR, VIOAR, and mostly limited the number of CHEAL weeds. In turn, the number of EROCI was best reduced by metribuzin applied after potato emergence and a mixture of herbicides, metribuzin + rimsulfuron + ethoxylated isodecyl alcohol, used before the emergence of the plants, while the numbers of SONAR and CAPBP were successfully eliminated by all herbicides.

The leaf-type cultivar "Fianna" (shorter stems, more branched, and denser and taller leaf canopy) proved to be less susceptible to weed infestation than the stem-type cultivar "Irga".

Selecting cultivars with a fast initial growth rate and a leaf crown capable of controlling weeds can help to reduce weed infestation in potato crops.

Author Contributions: Conceptualization: P.B. and B.S.; methodology: B.S., P.B., and P.P.; data protection: P.B., P.P., and B.S.; data curation-writing: P.B. and B.S.; funding acquisition: P.B.; software: P.P.; validation: P.P.; formal analysis: B.K.M.; investigation: B.K.M.; resources: B.K.M.; project administration: P.B.; writing一original draft preparation: P.B., B.S., B.K.M., and P.P.; writing—review and editing: B.S. and P.B.; visualization: B.S.; supervision: P.B. All authors have read and agreed to the published version of the manuscript. 
Funding: This research received no external funding.

Acknowledgments: The authors thank the management of the Institute of Plant Breeding and Seed Production, National Research Institute, for administrative and technical support.

Conflicts of Interest: The authors declare no conflict of interest.

\section{Abbreviation}

$\begin{array}{ll}\text { AGRRE } & \text { Agropyron repens (L). P. Beauv. } \\ \text { ECHCG } & \text { Echinochloa crus-galli (L.) P. Beauv } \\ \text { CAPBP } & \text { Capsella bursa-pastoris (L.) Medik. } \\ \text { CHEAL } & \text { Chenopodium album (L.) } \\ \text { CONAR } & \text { Convolvulus arvensis (L.) } \\ \text { EROCI } & \text { Erodium cicutarium (L.) L'HR } \\ \text { SONAR } & \text { Sonchus arvensis (L.) } \\ \text { VIOAR } & \text { Viola arvenis Murray } \\ \text { BBCH } & \text { Biologische Bundesanstalt, Bundessortenamt und CHemische Industrie } \\ \text { PRE } & \text { before potato emergence } \\ \text { POST } & \text { after potato emergence }\end{array}$

\section{References}

1. Riethmuller-Haage, I.; Bastiaans, L.; Kempenaar, C.; Smutny, V.; Kropff, M.; Kropff, M. Are pre-spraying growing conditions a major determinant of herbicide efficacy? Weed Res. 2007, 47, 415-424. [CrossRef]

2. Azadbakht, A. The effect of chemical and non-chemical control methods on weeds in potato (Solanum Tuberosum L.) cultivation in Ardabil province, Iran. Appl. Ecol. Environ. Res. 2017, 15, 1359-1372. [CrossRef]

3. Barbaś, P.; Sawicka, B. Dependence of potato crop on weed infestation. Agronom. Sci. 2020, 8, 346-359. [CrossRef]

4. Zarzecka, K.; Gugała, M.; Grzywacz, K.; Sikorska, A. Agricultural and economic effects of the use of biostimulants and herbicides in cultivation of the table potato cultivar Gawin. Acta Sci. Pol. Agric. 2020, 19, 3-10. [CrossRef]

5. Lavlesh Raghav, M.; Sati, U.C.; Sati, K. Evaluating the manual and chemical methods for weed control in potato (Solanum tuberosum L.) under Tarai conditions of Uttarakhand. Int. Q. J. Life Sci. 2017, 12, 683-686.

6. Mayerová, M.; Madaras, M.; Soukup, J. Effect of chemical weed control on crop yields in different crop rotations in a long-term field trial. Crop. Prot. 2018, 114, 215-222. [CrossRef]

7. Caldiz, D.; de Lasa, C.; Bisio, P.E. Grass and weed management in potato (Solanum tuberosum L.) processing with Clomazone, in Argentine pampas. Am. J. Plant Sci. 2016, 7, 2339-2348. [CrossRef]

8. Pawlonka, Z. Potato yield in monoculture under differentiated intensity of weed control. Prog. Plant Prot. Postępy Ochr. Roślin 2007, 47, 229-233.

9. Ryzak, M.; Bartmiński, P.; Bieganowski, A. Methods of determination of granulometric distribution of mineral soils. Theses and monographs. Acta Agroph. 2009, 175, 1-97.

10. Tomlin, C. The e-Pesticide Manual; Version 5.2; British Crop Production Council: Hampshire, UK, 2011.

11. Domaradzki, K.; Badowski, M.; Filipiak, K.; Franek, M.; Gołębiowska, H.; Kieloch, R.; Kucharski, M.; Rola, H.; Rola, J.; Sadowski, J.; et al. Field experiments. In Methodology Experiments of Biological Evaluation of Herbicides, Bioregulators and Adjuvants; Domaradzki, K., Ed.; Institute of Soil Science and Plant Cultivation Publishing House: Puławy, Poland, 2001; Chapter 1, p. 167. (In Polish)

12. Roztropowicz, S. (Ed.) Methodic of Observation, Measurements and Sample Take in Agricultural Experiments with Potato; Plant Breeding Acclimatization Institute, Section Jadwisin: Wołomin, Poland, 1999; p. 50.

13. SAS. I.I. SAS/STAT ${ }^{\circledR 9}$ 9.2. Users Guide; SAS: Cary, NC, USA, 2008.

14. John, H.M. Handbook of Biological Statistics, 3rd ed.; Sparky House Publishing: Baltimore, MD, USA, 2014; pp. 148-151.

15. PN-R-0403. Chemical and Agricultural Analysis of Soil. Sampling; Polish Committee for Standardization: Warsaw, Poland, 1997.

16. WRB. World Reference Database for Soil Resources. 2014. Available online: http://www.fao.org/3/a-i3794e.pdf (accessed on 8 June 2020). 
17. ISO (the International Organization for Standardization). ISO 10390: 2005, Soil Quality—Determination of $p H$; Technical Committee: ISO/TC 190/SC 3; Chemical and Physical Characteristics; ICS: 13.080.10. Chemical Characterization of Soils; ISO (The International Organization for Standardization): Geneva, Switzerland, 2005; Volume 2, pp. 1-7.

18. KQ-07/PO-01/F-02. Version 09/07.04.2014. Regional Chemical And Agricultural Station in Lublin, Poland. 2014. Available online: http://www.oschr.pl/instrukcje/2_GO_dn_2014_01_21.pdf (accessed on 30 August 2020).

19. PN-R-04020,1994+AZ1. Chemical and Agricultural Analysis of Soil; Polish Committee for Standardization: Warsaw, Poland, 2004.

20. PN-R-04023. Chemical and Agricultural Analysis of Soil. Determination of Available Phosphorus Content in Mineral Soils; Polish Committee for Standardization: Warsaw, Poland, 1996.

21. PN-R-04022,1996+AZ1. Chemical and Agricultural Analysis of Soil. Determination of Available Potassium Content in Mineral Soils; Polish Committee for Standardization: Warsaw, Poland, 2002.

22. Nawrocki, S. Fertilizer Recommendations. Part. I. Limit Numbers for Valuation of Soils in Macro and Microelements; IUNG: Puławy, Poland, 1990; Volume 44.

23. Rindler, W. Visual horizons in models of the world. Mon. Not. R. Astron. Soc. 1956, 116, 662-677, reprinted in Gen. Rel. Grav. 2002, 34, 133-153. [CrossRef]

24. Andreasen, C.; Streibig, C. Evaluation of changes in weed flora in arable fields of Nordic countries based on Danish long-term surveys. Weed Res. 2010, 51, 214-226. [CrossRef]

25. Grundy, A.C.; Mead, A.; Bond, W.; Clark, G.; Burston, S. The impact of herbicide management on long-term changes in the diversity and species composition of weed populations. Weed Res. 2010, 51, 187-200. [CrossRef]

26. Stešević, D.; Jovović, Z. Contribution to the knowledge on the weed flora in potato crop in the vicinity of Nikšić (Montenegro). Herb 2011, 12, 1-6.

27. Mayerová, M.; Mikulka, J.; Kolářová, M.; Soukup, J. Changes in weed community composition in a long-term trial with different crop rotations and herbicide treatments. Julius-Kühn-Archiv 2018, 458, 58-66.

28. Soren, C. Weed dynamics and yield of potato as influenced by weed management practices. Int. J. Pure Appl. Biosci. 2018, 6, 398-408. [CrossRef]

29. Ciesielska, A.; Wysmułek, A. The efficacy of tank mixture herbicides Sencor $600 \mathrm{SC}+$ Rimsulfuron in potatoes. Prog. Plant Protect. Postępy Ochr. Roślin 2012, 52, 885-888. [CrossRef]

30. Nowak, S.; Waindzoch, K.; Świerszcz, S.; Niemczyk, M.; Spałek, K.; Nowak, A. Crop density rather than ruderal plants explains the response of ancient segetal weeds. Biologia 2018, 74, 351-359. [CrossRef]

31. Ilić, O.; Nikolić, L.; Ilin, Ž.; Mišković, A.; Vujasinović, V.; Kukić, B. Effect of cultural practices on weeds community in function of potato yield. Acta Sci. Pol. Hortorum Cultus 2016, 15, 31-43.

32. Woźnica, Z.; Idziak, R.; Szewczyk, R.A. New multifunctional adjuvant for glyphosate-based herbicides. Prog. Plant Protect. Postępy Ochr. Roślin 2004, 44, 536-542.

33. Idziak, R.; Woźnica, Z. Skuteczność chwastobójcza herbicydu Callisto 100 SC stosowanego z adiuwantami i nawozem mineralnym. Acta Agroph. 2008, 11, 403-410.

34. Pacanoski, Z. Role of adjuvants on herbicide behavior, a review of different experiences. Herb 2010, 11, 67-79.

35. Villa, P.M.; Rodrigues, A.C.; Márquez, N.; Rodrigues, A.L.; Martins, S.V. Fitosociologíe de malezas después de un cultivo de papa (Solanum tuberosum L.) en los andes venezolanos: Un enfoque agroecologico. Phytosociology of weeds after potato cultivation (Solanum tuberosum L.) in the Venezuelan Andes: An agroecological approach. Trop. Subtrop. Agroecosystems 2017, 20, 329-339.

36. Gajbhiye, V.T.; Gajbhiye, V.T. Effect of concentration, moisture and soil type on the dissipation of flufenacet from soil. Chemosphere 2002, 47, 901-906. [CrossRef]

37. Wang, C.J.; Liu, Z.Q. Foliar uptake of pesticides-Present status and future challenge. Pestic. Bioch. Physiol. 2007, 87, 1-8. [CrossRef]

38. Stagnari, F.; Chiarini, M.; Pisante, M. Influence of fluorinated surfactants on the efficacy of some post-emergence sulfonylurea herbicides. J. Pestic. Sci. 2007, 32, 16-23. [CrossRef]

39. Kwiatkowski, C.A.; Wesołowski, M.; Drabowicz, M.; Misztal-Majewska, B. The effect of adjuvants and reduced rates of crop protection agents on the occurrence of agricultural pests and on winter wheat productivity. Ann. UMCS 2012, E-67, 12-21. 
40. Gugała, M.; Zarzecka, K.; Dołęga, H.; Sikorska, A. Weed infestation and yielding of potato under conditions of varied use of herbicides and bio-stimulants. J. Ecol. Eng. 2018, 19, 191-196. [CrossRef]

41. Kierzek, R.; Paradowski, A.; Kaczmarek, S. Chemical methods of weed control in maize (Zea mays L.) in variable weather conditions. Acta Sci. Pol. Agric. 2012, 11, 35-52.

42. Johnson, K.; Jacobsen, C.S.; Torsvik, V.; Sørensen, J. Pesticide effects on bacterial diversity in agricultural soils-A review. Biol. Fertil. Soils 2001, 33, 443-453. [CrossRef]

43. Meena, R.S.; Kumar, S.; Datta, R.; Lal, R.; Vijayakumar, V.; Brtnický, M.; Sharma, S.K.; Yadav, G.S.; Jhariya, M.K.; Jangir, C.K.; et al. Impact of agrochemicals on soil microbiota and management: A review. Land 2020, 9, 34. [CrossRef]

44. Ramsey, R.J.L.; Stephenson, G.R.; Hall, J.C. Review of the effect of moisture, humectants and surfactant composition on the absorption and effectiveness of highly water-soluble herbicides. Biochem. Pestic. Phys. 2005, 82, 162-175. [CrossRef]

45. Awasthi, R.; Gaur, P.M.; Turner, N.C.; Vadez, V.; Siddique, K.H.M.; Nayyar, H. Effects of individual and combined heat and drought stress during seed filling on the oxidative metabolism and yield of chickpea (Cicer arietinum) genotypes differing in heat and drought tolerance. Crop. Pasture Sci. 2017, 68, 823. [CrossRef]

46. Spanogiannopoulos, P.; Bess, E.N.; Carmody, R.N.; Turnbaugh, P.J. The microbial pharmacists within us: A metagenomic view of xenobiotic metabolism. Nat. Rev. Genet. 2016, 14, 273-287.

47. Frąc, M.; Jezierska-Tys, S. Diversity of soil environment microorganisms. Adv. Microb. 2010, 40, 47-58.

48. Zarzecka, K.; Gugała, M.; Dołega, H. Regulation of weed infestation degree in potato with the use of herbicides. Biul. IHAR 2013, 267, 113-120.

49. Tomczak, B.; Bączkowska, E.; Bubniewicz, P.; Górniak, J. Prosulfocarb-Herbicide for monocot and dicot weed control in winter cereals and potatoes. Prog. Plant Protect. Postępy Ochr. Roślin 2007, 47, 280-284.

50. Pszczółkowski, P.; Sawicka, B. Attempts to reduce weed infestation of potato in cultivation under cover. Part II. Weight, abundance and species composition of weeds. Biul. IHAR 2003, 228, 261-273.

51. Wichrowska, D. Weed infestation of potato plantation cultivated in Kujawsko-Pomorski Region. Eko Tech 2008, 16, 91-96.

52. Baranowska, A.; Mystkowska, I.; Zarzecka, K.; Gugała, M. Efficacy of herbicides in potato crop. J. Ecol. Eng. 2016, 17, 82-88. [CrossRef]

53. Boydston, R.A. Managing weeds in potato rotations without herbicides. Am. J. Potato Res. 2010, 87, 420-427. [CrossRef]

54. Sawicka, B. Resilient Agricultural Practices. In Zero Hunger. Encyclopedia of the UN Sustainable Development Goals; Leal Filho, W., Azul, A., Brandli, L., Özuyar, P., Wall, T., Eds.; Springer: Cham, Switzerland, 2020.

55. De Cicco, A.; Jeanty, J.C. Potato Sector in the EU-Production, Price and Trade Statistics. EUROSTAT. Statistic Explained. Available online: https://ec.europa.eu/eurostat/statistics-explained/index.php/The_EU_potato_ sector_-_statistics_on_production,_prices_and_trade (accessed on 14 August 2020). 